OPEN ACCESS

Edited by:

Venkataraman Thangadurai,

University of Calgary, Canada

Reviewed by:

Stephen Skinner,

Imperial College London,

United Kingdom

Domingo Pérez-Coll,

Consejo Superior de Investigaciones

Científicas (CSIC), Spain

${ }^{*}$ Correspondence:

M. Grant Norton

mg_norton@wsu.edu

SuY. Ha

suha@wsu.edu

Specialty section:

This article was submitted to

Fuel Cells,

a section of the journal Frontiers in Energy Research

Received: 06 June 2018 Accepted: 13 August 2018

Published: 31 August 2018

Citation:

Zhao K, Kim B-H, Norton MG and Ha SY (2018) Cathode Optimization

for an Inert-Substrate-Supported

Tubular Solid Oxide Fuel Cell.

Front. Energy Res. 6:87.

doi: 10.3389/fenrg.2018.00087

\section{Cathode Optimization for an Inert-Substrate-Supported Tubular Solid Oxide Fuel Cell}

\author{
Kai Zhao ${ }^{1}$, Bok-Hee Kim ${ }^{2}$, M. Grant Norton ${ }^{1,3 *}$ and Su Y. Ha ${ }^{1 *}$ \\ ${ }^{1}$ Voiland School of Chemical Engineering and Bioengineering, Washington State University, Pullman, WA, United States, \\ ${ }^{2}$ Division of Advanced Materials Engineering, Chonbuk National University, Jeonbuk, South Korea, ${ }^{3}$ School of Mechanical \\ and Materials Engineering, Washington State University, Pullman, WA, United States
}

Inert-substrate-supported tubular solid oxide fuel cells with multi-functional layers were fabricated in this work. The tubular single cells consisted of a porous yttria-stabilized zirconia inert-substrate supporting layer, a $\mathrm{Ni}$ anode current collecting layer, a $\mathrm{Ni}-\mathrm{Ce}_{0.8} \mathrm{Sm}_{0.2} \mathrm{O}_{1.9}$ anode electrochemical layer, an yttria-stabilized zirconia/ $\mathrm{Ce}_{0.8} \mathrm{Sm}_{0.2} \mathrm{O}_{1.9}$ bi-layer electrolyte, and a $\mathrm{La}_{0.6} \mathrm{Sr}_{0.4} \mathrm{Co}_{0.2} \mathrm{Fe}_{0.8} \mathrm{O}_{3-\delta}$ cathode. Thickness of the $\mathrm{La}_{0.6} \mathrm{Sr}_{0.4} \mathrm{Co}_{0.2} \mathrm{Fe}_{0.8} \mathrm{O}_{3-\delta}$ cathode layer could be varied from 2.5 to $25.0 \mu \mathrm{m}$ by controlling the number of dip-coatings in the single cell fabrication process. Electrochemical performance of the tubular single cells was investigated as a function of cathode thickness. Area specific resistance and maximum power density of the single cell were significantly affected by the thickness of the cathode. Increasing the cathode thickness to $15 \mu \mathrm{m}$ was effective in reducing the sheet resistance of the layer and the area specific resistance of the single cell. Further increasing the cathode thickness induced a higher electrode polarization loss, which originated from insufficient gas diffusion and transport processes. Therefore, the optimum thickness of the $\mathrm{La}_{0.6} \mathrm{Sr}_{0.4} \mathrm{Co}_{0.2} \mathrm{Fe}_{0.8} \mathrm{O}_{3-\delta}$ cathode layer was determined to be $15 \mu \mathrm{m}$. At $800^{\circ} \mathrm{C}$, the tubular single cell with the optimum cathode thickness displayed the highest observed maximum power density of $559 \mathrm{mWcm}^{-2}$ under the hydrogen/air operation mode. Additionally, the tubular single cell exhibited good thermal cycling stability between 800 and $25^{\circ} \mathrm{C}$ for five cycles. These results illustrate the advantages of this system for future applications of the inert-substrate-supported tubular single cells in repeated startup and shut down conditions.

\footnotetext{
Keywords: cathode thickness, inert substrate supported tubular cell, sheet resistance, polarization, electrochemical performance, thermal cycling, tubular solid oxide fuel cell
}

\section{INTRODUCTION}

Solid oxide fuel cells (SOFCs) are electrochemical devices that convert chemical energy into electricity. As the chemical energy present in fuels is directly converted into electrical energy, SOFCs show a higher energy conversion efficiency than conventional gas turbine engines (Stambouli and Traversa, 2002; Kirubakaran et al., 2009). Compared to widely developed button type SOFCs, tubular type SOFCs exhibit benefits of reduced sealing area and improved mechanical 
properties. Hence, they can be applied for fast startup and shutdown operating conditions, which is a significant advantage for future commercialization (Singhal, 2012; Orera et al., 2014). In the past several decades, the Ni-yttria-stabilized zirconia (YSZ) anode supported single cell configuration has been regarded as the mainstream for SOFC developments. This is due to the high conductivity of the nickel cermet, good electrocatalytic activity and low electrode polarization (Singhal, 2012; Shri Prakash et al., 2014). However, the thermal expansion coefficient (TEC) of the Ni-YSZ anode (with a Ni content $>50$ vol.\%) is much higher than typical YSZ and doped-ceria electrolyte materials. The mismatch in TEC between bulk Ni-YSZ and the electrolyte layers may induce cracks in the electrolyte and eventual failure of the single cell (Aruna et al., 1998; Sameshima et al., 1999; Hayashi et al., 2005).

To match the TECs between the supporting layer and the electrolyte layer, the thermal and mechanical properties of $\mathrm{Ni}$ YSZ has been investigated with respect to the nickel content in the cermet. Lowing the nickel content was found to be effective in reducing the TEC of Ni-YSZ, and the Ni-YSZ cermet with 15 vol.\% of Ni exhibits TEC of $1.04 \times 10^{-5} \mathrm{~K}^{-1}$, which is comparable with that of YSZ $\left(1.05 \times 10^{-5} \mathrm{~K}^{-1}\right.$; Aruna et al., 1998; Hayashi et al., 2005). On the other hand, the insufficient nickel loading (15 vol.\%) in the anode leads to poor connectivity between the nickel grains. Hence, the anode displays an unsatisfactory electronic conductivity of $\sim 0.103 \mathrm{~S} \mathrm{~cm}^{-1}$ at $900^{\circ} \mathrm{C}$, resulting in evidently high ohmic loss of the single cells and reduction in the maximum power density (Aruna et al., 1998). In order to maintain mechanical compatibility between the supporting layer and the electrolyte in the single cell while ensuring sufficient electronic conductivity in the anode layer, a porous YSZ inert-substrate-supported tubular single cell design was developed (Zhao et al., 2014, 2016) with the following configuration:

- Porous YSZ supporting layer

- $\mathrm{Ni}-\mathrm{Ce}_{0.8} \mathrm{Sm}_{0.2} \mathrm{O}_{1.9}$ (Ni-SDC) anode

- YSZ/SDC bi-layer electrolyte

- $\mathrm{La}_{0.6} \mathrm{Sr}_{0.4} \mathrm{Co}_{0.2} \mathrm{Fe}_{0.8} \mathrm{O}_{3-\delta}$ (LSCF) cathode.

As the YSZ was used as the supporting layer, the TEC of the substrate should match that of the YSZ/SDC bi-layer electrolyte (TEC of YSZ is $10.5 \times 10^{-6} \mathrm{~K}^{-1}$ and TEC of SDC is $11.8 \times 10^{-6} \mathrm{~K}^{-1}$ from 200 to $1,000^{\circ} \mathrm{C}$; Sameshima et al., 1999; Hayashi et al., 2005). To ensure the high electronic conductivity and electrochemical activity, $50 \mathrm{vol} \%$ of Ni-50 vol.\% of SDC anode was applied as a functional layer (10$20 \mu \mathrm{m}$ ) on the outer surface of the porous YSZ substrate. According to previous thermo-mechanical simulation studies, reducing the thickness of the anode layer from the millimeter range to the micrometer range is effective in reducing the stress generated by the thermal expansion mismatch (Yakabe et al., 2004; Sarantaridis and Atkinson, 2007). Thus, a thin anode layer $(10-20 \mu \mathrm{m})$ applied in the tubular cell was expected to minimize the stress between the various functional layers in the cell. This expectation was validated by previous experimental work on redox cycling performance of the tubular single cells (Zhao et al., 2014).
In previous study, the initial electrochemical performance and redox cycling stability of the tubular single cells were optimized by controlling the microstructure of the anode layer. For example, the fabrication parameters (such as the porosity of the YSZ substrate and the number of dip-coatings for the anode layer) were tailored to achieve the optimum anode microstructure (Zhao et al., 2014). Despite the previous work on performance improvement for the tubular single cells $\left(300-400 \mathrm{~mW} \mathrm{~cm}{ }^{-2}\right.$ at $\left.800^{\circ} \mathrm{C}\right)$, the maximum power density was still lower than conventional button-type $\mathrm{Ni}$ $\mathrm{Sm}, \mathrm{Gd}$-doped ceria anode single cells $\left(\sim 900 \mathrm{~mW} \mathrm{~cm}^{-2}\right.$ at $650^{\circ} \mathrm{C}$; Fu et al., 2010). Experimental results revealed that the tubular single cell displayed a significantly larger area specific resistance $\left(\sim 0.90 \Omega \mathrm{cm}^{2}\right.$ at $\left.800^{\circ} \mathrm{C}\right)$ under the opencircuit voltage condition than the conventional button-type $\mathrm{Ni}$-SDC anode single cell $\left(0.41 \Omega \mathrm{cm}^{2}\right.$ at $600^{\circ} \mathrm{C}$; Fu et al., 2010; Zhao et al., 2014). Considering the Ni-containing anode employed in the cell, the area specific resistance arising from the cathode side would be regarded as an important contributor to the total polarization resistance of our tubular single cell.

The oxygen reduction on the surface of the LSCF cathode involves the following steps: (1) oxygen diffusion to the cathode surface, (2) adsorption and dissociation of oxygen on the cathode surface, (3) electron charge transfer between the cathode surface and adsorbed oxygen, (4) diffusion of oxygen ions in the cathode bulk phase, and (5) oxygen ion charge transfer at the interface between the cathode and the electrolyte (Adler, 2004; Li et al., 2010; Gong et al., 2012). Steps (3)-(5) are mainly determined by the intrinsic electronic-ionic mixed conducting properties of the cathode material, while steps (1) and (2) are highly dependent on the extrinsic microstructure of the cathode. To minimize the cathode polarization, microstructural features, such as porosity, grain size and adhesion between grains in the cathode were optimized by adjusting the pore former contents in the cathode slurry, the particle size of the starting powders, and the sintering temperature of the electrode (Perry Murray et al., 2002; Murata et al., 2005; Gostovic et al., 2007), respectively. However, the effect of cathode thickness on overall electrochemical performance of the inertsubstrate-supported tubular single cell has not been satisfactorily addressed. Further research efforts to elucidate the relationship between the cathode thickness and electrochemical activity of the tubular single cell could provide a guideline for improving overall cell performance.

In this work, a porous YSZ inert-substrate-supported tubular single cell was fabricated by an extrusion and slurry dipcoating method. Thickness of the LSCF cathode layer was adjusted by varying the number of dip-coatings from one up to six. The electrochemical performance of the tubular single cell was determined as the function of cathode thickness. The optimum cathode thickness being when the maximum power density of the tubular single cells was obtained. Additionally, the thermal cycling performance of the tubular single cell was investigated to understand its mechanical stability under repetitive startup and shut down operating conditions. 


\section{MATERIALS AND METHODS}

\section{Powder Preparation}

The NiO-SDC powder containing 61.3 wt.\% NiO and 38.7 wt.\% SDC was obtained by urea combustion synthesis. Reagent grade $\mathrm{Ni}\left(\mathrm{NO}_{3}\right)_{2} \cdot 6 \mathrm{H}_{2} \mathrm{O}$ (High Purity Chemicals), $\mathrm{Ce}\left(\mathrm{NO}_{3}\right)_{3} \cdot 6 \mathrm{H}_{2} \mathrm{O}$ (Alfa Aesar), $\mathrm{Sm}\left(\mathrm{NO}_{3}\right)_{3} \cdot 6 \mathrm{H}_{2} \mathrm{O}$ (Alfa Aesar) and urea (Alfa Aesar) were used as starting materials. These starting materials were dissolved into deionized water to form a solution. The mole ratio of urea to the total metal cation content was 2.0 according to our previous results (Chen et al., 2008). This solution was stirred for $1 \mathrm{~h}$ and heated on a hot plate until auto-ignition and self-sustaining combustion occurred. The obtained ash was subsequently ground for $24 \mathrm{~h}$ in ethanol medium using a ball milling process with zirconia balls. Then the powder was calcined at $1,000^{\circ} \mathrm{C}$ for $2 \mathrm{~h}$ in air.

The LSCF cathode powder with the nominal composition of $\mathrm{La}_{0.6} \mathrm{Sr}_{0.4} \mathrm{Co}_{0.2} \mathrm{Fe}_{0.8} \mathrm{O}_{3-\delta}$ was synthesized by a glycine-nitrate combustion. Reagent grade $\mathrm{La}\left(\mathrm{NO}_{3}\right)_{3} \cdot 6 \mathrm{H}_{2} \mathrm{O}$ (Kanto Chemical), $\mathrm{Sr}\left(\mathrm{NO}_{3}\right)_{2}$ (Sigma Aldrich), $\mathrm{Co}\left(\mathrm{NO}_{3}\right)_{3} \cdot 6 \mathrm{H}_{2} \mathrm{O}$ (Sigma Aldrich), $\mathrm{Fe}\left(\mathrm{NO}_{3}\right)_{3} \cdot 9 \mathrm{H}_{2} \mathrm{O}$ (Kanto Chemical) and glycine (Samchun Chemical) were used as raw materials. These nitrates were weighed, respectively, according to the nominal composition, and dissolved into deionized water to form a solution. The mole ratio of glycine to the total metal cation content was selected as 3.0 according to our previous results (Zhao et al., 2011). This solution was stirred for $1 \mathrm{~h}$ and heated on a hot plate until auto-ignition and self-sustaining combustion occurred. The obtained ash was subsequently ground for $24 \mathrm{~h}$ in ethanol medium using a ball milling process with zirconia balls. Then the powder was calcined at $700^{\circ} \mathrm{C}$ for $2 \mathrm{~h}$ in air. The details of the powder fabrication procedure have been described elsewhere (Zhao et al., 2013).

\section{Fabrication of the Single Cell}

Porous YSZ inert-substrate supports were fabricated by an extrusion process using 25 wt.\% poly(methyl-methacrylate) (Sunjin Chemical) pore former mixed with 75 wt.\% YSZ powder $\left(\mathrm{Zr}_{0.92} \mathrm{Y}_{0.08} \mathrm{O}_{2-\delta}, 99.9 \%\right.$, Tosoh). The inner and outer diameters of the tubes were 3.4 and $6.0 \mathrm{~mm}$, respectively.

The Ni anode current collector layer was deposited onto the outer surface of the YSZ tube by dip-coating using 16 wt.\% $\mathrm{NiO}$ (99.995\%, Alfa Aesar) and 1.8 wt.\% poly(methylmethacrylate) powders dispersed in an organic carrier (I) by ball milling for $24 \mathrm{~h}$. The organic carrier (I) consisted of 0.5 wt.\% triethanolamine (>99\%, Alfa Aesar), 1.0 wt.\% dibutyl phthalate (>99\%, Alfa Aesar), 1.0 wt.\% polyethylene glycol 300 (>99\%, Showa Chemical), 1.5 wt.\% polyvinyl butyral (Sigma Aldrich), 48 wt.\% 2-butanone (99\%, Alfa Aesar), and 48 wt.\% ethanol (Hayman Specialty Products). The NiO slurry was dip-coated onto the YSZ surface and dried in air for $24 \mathrm{~h}$. The layer was then calcined at $500^{\circ} \mathrm{C}$ for $1 \mathrm{~h}$ in air. The $\mathrm{NiO}-\mathrm{SDC}$ anode layer with $60 \mathrm{wt} \% \mathrm{NiO}$ and 40 wt.\% SDC was deposited over the $\mathrm{NiO}$ layer in the same way by dipcoating.

After fabricating the anode layer, the YSZ $\left(\mathrm{Zr}_{0.92} \mathrm{Y}_{0.08} \mathrm{O}_{2-\delta}\right)$ electrolyte was deposited on the outer surface of the tube by dip-coating using 17 wt.\% YSZ powder mixed in organic carrier (II) by ball milling for $24 \mathrm{~h}$. The organic slurry (II) was comprised of 30 wt.\% ethanol, 30 wt.\% B73210 organic binder (Ferro Electronic Materials), and 40 wt.\% $\alpha$-terpineol (>96\%, Sigma Aldrich). The YSZ slurry was dip-coated onto the NiOSDC anode layer. The SDC layer was fabricated over the YSZ electrolyte layer by the same process. Then, the green tube was cosintered at $1,400^{\circ} \mathrm{C}$ for $4 \mathrm{~h}$ in air. The inner and outer diameters of the tube were reduced to 2.5 and $4.5 \mathrm{~mm}$, respectively. The detailed fabrication procedure was reported in our previous publication (Zhao et al., 2014).

Finally, 10 wt.\% LSCF powder was mixed with 90 wt.\% lab-made organic carrier (III) by ball-milling for $24 \mathrm{~h}$ to form the cathode slurry. Organic carrier (III) comprised 0.5 wt.\% triethanolamine, 1.0 wt.\% polyethylene glycol 300, 1.0 wt.\% dibutyl phthalate, $3.5 \mathrm{wt} . \%$ polyvinyl butyral, $31 \mathrm{wt} \%$ ethanol, and 63 wt.\% 2-butanone. The dip-coating process was repeated from one to six times to adjust the thickness of the cathode. After the dip-coating process, the cathode layer was sintered at $950^{\circ} \mathrm{C}$ for $2 \mathrm{~h}$ in air.

\section{Structural Characterization}

The porosity of the YSZ substrate was measured by the Archimedes' method and was determined to be $\sim 39 \%$ after sintering at $1,400^{\circ} \mathrm{C}$ for $4 \mathrm{~h}$ in air. The microstructure of the tubular single cells was examined by scanning electron microscopy (SEM, JSM-6400, JEOL). Features of the cathode layer such as grain size, porosity and thickness were estimated using Image-Pro Plus 6.0 software (Iwanschitz et al., 2012).

\section{Electrical Resistance}

The sheet resistance of the cathode layer was measured by a four-probe method at $800^{\circ} \mathrm{C}$ in air. The experimental setup for measuring the sheet resistance of the cathode layer is shown in Figure 1A. The sheet resistance $(R s)$ of the cathode layer was calculated by the following equation (Zhao et al., 2014):

$$
R s=(U / I) \cdot(\pi \cdot D) / L
$$

where $I$ is the current applied between line $\mathrm{E}$ and line $\mathrm{F}$, and $U$ is the voltage measured between $A$ and B. $D$ is the outer diameter of the tubular single cell and $L$ is the distance between $\mathrm{A}$ and $\mathrm{B}$. As the conductivity of SDC $\left(\sim 0.082 \mathrm{~S} \mathrm{~cm}^{-1}\right)$ is three orders of magnitude lower than that of LSCF $\left(\sim 200 \mathrm{~S} \mathrm{~cm}^{-1}\right)$ at $800^{\circ} \mathrm{C}$ in air, the SDC layer shows a minor effect on the measured sheet resistance of the LSCF layer (see the Supplementary Material; Mineshige et al., 2005; Chen M. et al., 2009). Additionally, according to previous research results, the conductivities of YSZ and $\mathrm{NiO}-Y S Z$ layers were even lower than that of SDC layer in air (Eguchi, 1997). Hence, the YSZ, NiO-YSZ and the porous YSZ substrate layers are expected to have no evident effects on the measured sheet resistance of the LSCF layer. Therefore, the sheet resistance that we measured in this study truly represents the sheet resistance of the LSCF layer. 

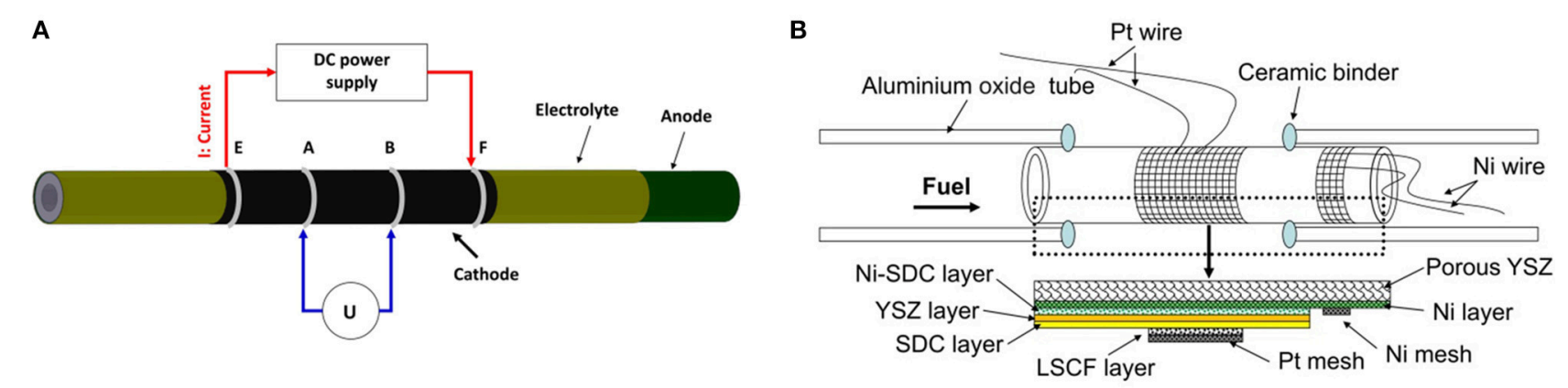

FIGURE 1 | (A) Schematic diagram of sheet resistance measurement setup, and (B) Schematic diagram of tubular single cells.

\section{Cell Performance Measurement}

Electrochemical performance of the tubular single cell was investigated by an in-house-designed fuel cell testing system (shown in Figure 1B). The system consists of an electrochemical workstation (SP 150, Biologic SAS), a set of mass flow controllers (FM-30VE, Line Tech), and alumina single cell holders. Platinum wire (wire diameter: $1 \mathrm{~mm}$ ) and platinum mesh (mesh size: $40 \times$ 40, wire diameter: $0.1 \mathrm{~mm}$ ) were used as the current collectors for the cathode, while nickel wire and nickel mesh were used as the current collectors for the anode. The tubular single cell was sealed to the alumina single cell holders by an aluminabased ceramic binder (AREMCO Products). Electrochemical cell characterization was performed using dry hydrogen (200 $\mathrm{sccm}$ ) as fuel and air as the oxidant at $800^{\circ} \mathrm{C}$. Electrochemical impedance spectra of the tubular single cells were measured under the open-circuit voltage (OCV) condition in the frequency range of $0.01 \mathrm{~Hz}-100 \mathrm{kHz}$, and the amplitude of the sinuous signal was $10 \mathrm{mV}$ in the potentiostatic mode.

Thermal cycling stability of the single cell was tested between 800 and $25^{\circ} \mathrm{C}$ with hydrogen as fuel and air as oxidant. For each cycle, the single cell was heated to $800^{\circ} \mathrm{C}$ at $4^{\circ} \mathrm{C} \mathrm{min}^{-1}$, and performance stability was measured at $800^{\circ} \mathrm{C}$ for $\sim 5 \mathrm{~h}$. Then, the cell was cooled down to $25^{\circ} \mathrm{C}$ at $4^{\circ} \mathrm{C} \mathrm{min}{ }^{-1}$. The thermal cycling process was repeated five times in this present study.

\section{RESULTS}

\section{Microstructural Characterization}

Figure 2 shows cross-sectional SEM images of the inertsubstrate supported tubular single cells fabricated by dip-coating. Figure 2A illustrates the full single cell with the porous YSZ substrate, Ni anode current collector, Ni-SDC anode, YSZ/SDC bi-layer electrolyte, and the LSCF cathode. The LSCF layer was dip-coated for four times. Good adhesion appears to have been obtained between the different functional layers in the cells. Figures 2B-D shows typical SEM images of the cathode layer with the increasing thickness as the number of dipcoating steps goes from one to six. The LSCF layer coated once displayed some discontinuous regions, which could be ascribed to insufficient slurry wetting on the dense surface of the SDC electrolyte (Yamaguchi et al., 2007). After depositing a second
LSCF layer, no disconnected regions were identified by the SEM analysis. The improved wetting in the additional dip-coatings would be due to the enhanced capillary force generated from the previously deposited porous LSCF layer on the tubular single cells (Yamaguchi et al., 2007; Tikkanen et al., 2011). Generally, the thickness of the cathode was found to increase from 2.5 to $25 \mu \mathrm{m}$ as the number of dip-coatings varied from one to six.

\section{Sheet Resistance}

Figure 3 shows the sheet resistance of the cathode layer measured by the four-probe method at $800^{\circ} \mathrm{C}$ in air. The LSCF cathode layer dip-coated once displayed an extraordinarily high sheet resistance of $895 \Omega \mathrm{sq}^{-1}$, and high resistivity of $0.22 \Omega \mathrm{cm}$ (shown in Figure S2 in the Supplementary Material), which could be due to the discontinuities in the layer as shown in Figure 2B. When increasing the thickness of the layer by dip-coating twice, the sheet resistance significantly dropped from 895 to $46 \Omega$ $\mathrm{sq}^{-1}$. This drop in the sheet resistance could be ascribed to the uniformity of the overall layer produced by repetitive dipcoating. Further increasing the LSCF thickness by additional dipcoated layers decreased the sheet resistance from 46 to $3 \Omega \mathrm{sq}^{-1}$.

\section{Electrochemical Performance}

Electrochemical impedance spectra of the tubular single cells were measured at $800^{\circ} \mathrm{C}$ under the OCV condition. In the electrochemical impedance tests, several electrochemical processes, such as charge transfer, gas adsorption and dissociation, and gas diffusion in porous electrodes, can be overlapped with each other. In order to deconvolute electrochemical processes, the Distribution-Relaxation-Times (DTR) technique was used to analyze the measured impedance data (Ciucci and Chen, 2015; Wan et al., 2015). Figure 4 shows the typical distribution of resistances as a function of the frequency for the tubular single cells with different cathode thicknesses. Generally, two major peaks can be resolved in the frequency range $0.01 \mathrm{~Hz}-100 \mathrm{kHz}$. The high frequency peak was located at $4.3-7.4 \mathrm{~Hz}$, while the low frequency peak was at $0.24-0.31 \mathrm{~Hz}$. The results suggested two dominant electrode processes contributing to the overall electrode polarization in the tubular single cells. 

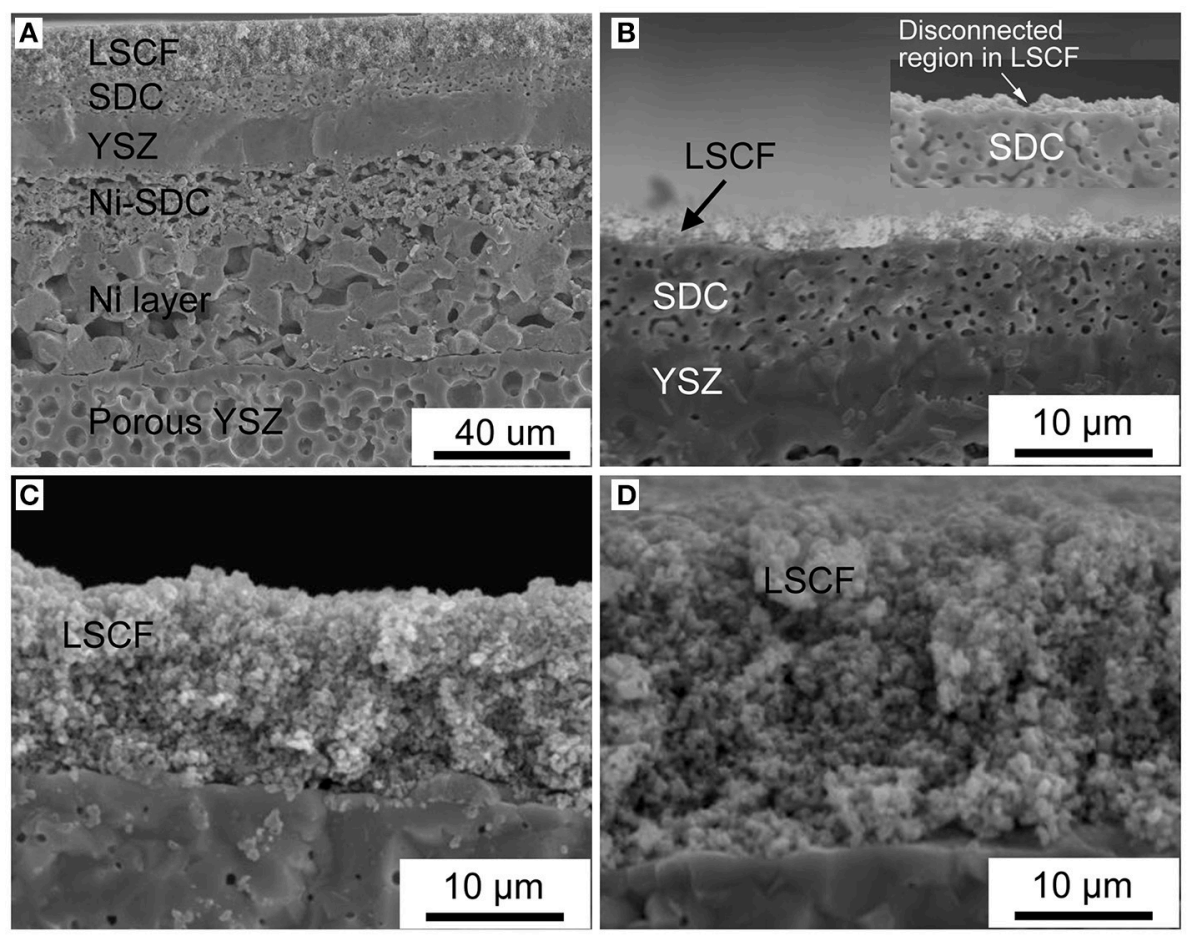

FIGURE 2 | (A) SEM image of the tubular single cell; (B-D) Cathode layers with the dip-coating time going from one, to four and then six, respectively.

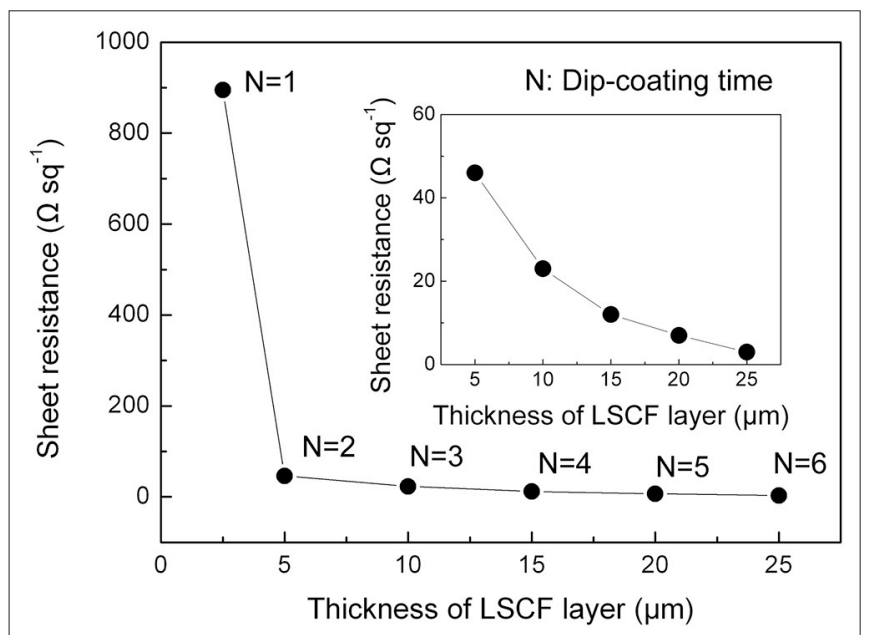

FIGURE 3 | Sheet resistance of the LSCF cathode layer vs. thickness.

Based on the results obtained from the DRT analysis, the electrochemical impedance spectra of the tubular single cells were fitted by the $L R_{\mathrm{ohm}}\left(R_{\mathrm{H}} Q_{\mathrm{H}}\right)\left(R_{\mathrm{L}} Q_{\mathrm{L}}\right)$ equivalent circuit model. Figure 5 shows the corresponding Nyquist plots of the tubular single cells and a schematic diagram of the equivalent circuit model. $L$ represents the inductive impedance response originating from the connecting wires and the measurement device. $R_{\mathrm{ohm}}$ is the ohmic resistance of the single cell. The $\left(R_{\mathrm{H}} Q_{\mathrm{H}}\right)\left(R_{\mathrm{L}} Q_{\mathrm{L}}\right)$ components refer to the electrode processes, where $R$ is the resistance and $Q$ is the constant phase element. The subscript $\mathrm{H}$ refers to the high frequency impedance response and $\mathrm{L}$ denotes the low frequency response. The equivalent capacitance $C$ and relaxation frequency $f$ corresponding to each electrode process are calculated by the following equations (Gourba et al., 2004; Chen D. et al., 2009):

$$
\begin{aligned}
& C=(R \cdot Q)^{1 / n} / R \\
& f=(R \cdot Q)^{-1 / n} /(2 \pi)
\end{aligned}
$$

where $n$ is an exponential parameter, which can be determined from the electrochemical impedance spectra fitting. The values of the chi-squared function $(x)$ are on the order of $10^{-4}$ for all the impedance spectra fittings, indicating reliable fitting results in this work (Küngas et al., 2009). The area specific resistance of the single cell $R_{\mathrm{p}}$ is the sum of $R_{\mathrm{H}}$ and $R_{\mathrm{L}}$. The electrochemical parameters obtained from the impedance spectra fittings are summarized in the Supplementary Material (Table S2). We found that the relaxation frequency data obtained from the impedance spectra fittings and DRT analyses (shown in Figure 4) were comparable. The similarity indicated the good reliability in both impedance spectra fittings and DRT analyses.

Figure 6 shows ohmic and polarization resistances of the tubular single cells with the thickness of the cathode layer varying from 5 to $25 \mu \mathrm{m}$. When increasing the thickness of the cathode layer from 5 to $15 \mu \mathrm{m}$, the ohmic resistance $\left(R_{\mathrm{ohm}}\right)$ of the tubular single cell displayed an evident decrease from 0.84 to $0.26 \Omega \mathrm{cm}^{2}$. Additionally, the area specific resistance $\left(R_{\mathrm{p}}\right)$ of the single cell presented a similar trend as well. The reduction of $R_{\mathrm{p}}$ values 

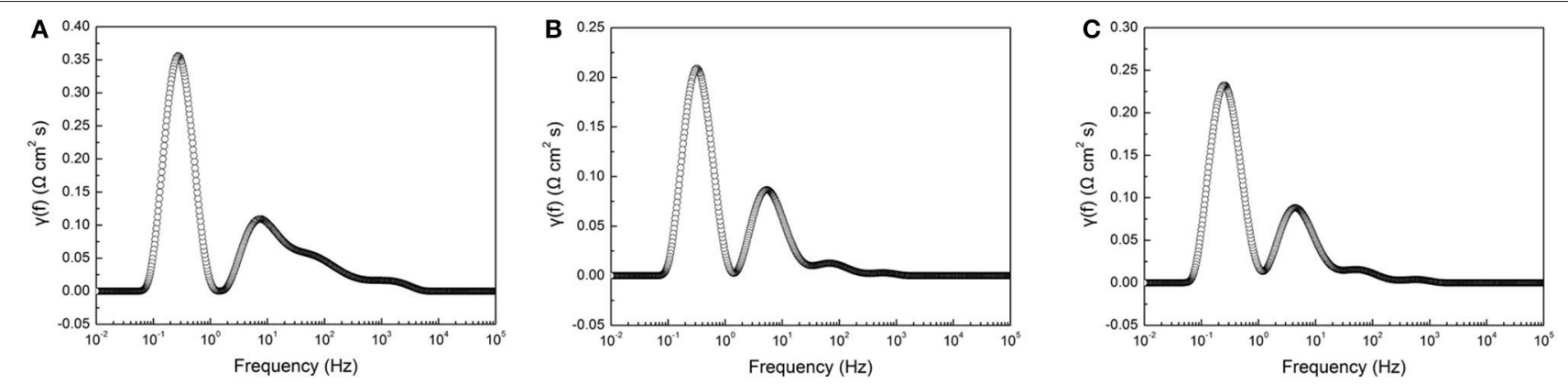

FIGURE 4 | DRT curves obtained from electrochemical impedance spectra of single cells with different cathode layer thicknesses: (A) $5 \mu \mathrm{m}$, (B) $15 \mu \mathrm{m}$, and (C) $20 \mu \mathrm{m}$.

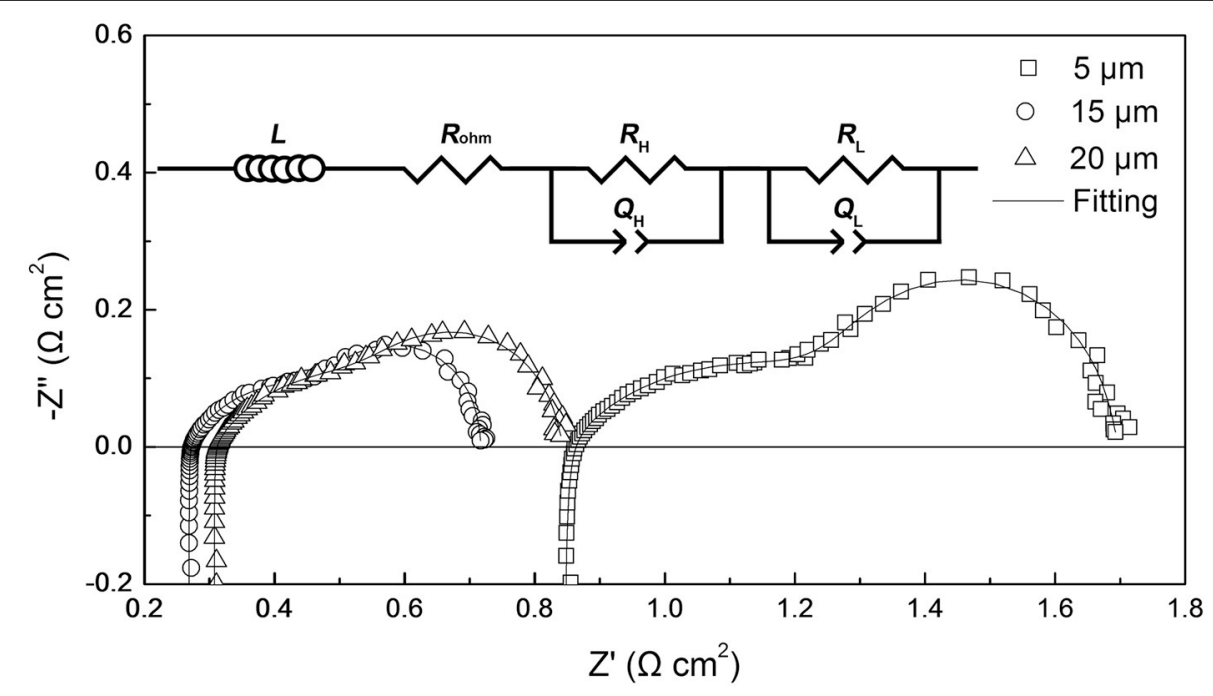

FIGURE 5 | Nyquist plots of the tubular single cells at $800^{\circ} \mathrm{C}$ under the $\mathrm{OCV}$ condition.

can be ascribed to the enhanced electrochemical process of the oxygen reduction with the thicker cathode up to $15 \mu \mathrm{m}$. On the other hand, increasing the thickness of the cathode beyond $15 \mu \mathrm{m}$ resulted in a minor increment of the $R_{\mathrm{p}}$ value. Thus, the optimum cathode thickness was determined to be $15 \mu \mathrm{m}$ based on the electrode polarization property.

Figure 7A shows cell voltage and power density curves of the tubular single cells as the function of current density at $800^{\circ} \mathrm{C}$ in dry hydrogen fuel. The OCV values of the single cells were $\sim 1.04 \mathrm{~V}$, being slightly lower than the theoretically predicted value (>1.10 V; Zha et al., 2001; Su et al., 2013). The lower OCV values could be ascribed to imperfect sealing and the minor short circuit originating from the thin YSZ/SDC bi-layer electrolyte layers in the cell. Figure 7B illustrates the variation of maximum power density of the tubular single cells with different cathode thicknesses. The maximum power density linearly increased from 224 to $559 \mathrm{~mW} \mathrm{~cm}^{-2}$ as the thickness of the cathode layer increased from 5 to $15 \mu \mathrm{m}$. Further increases in the thickness were not beneficial for improving maximum power density. Hence, the optimum thickness of the LSCF cathode layer was found to be $15 \mu \mathrm{m}$ for the inert-substrate-supported tubular single cell, which agrees with the data obtained from electrochemical impedance data shown in Figures 5, 6.

\section{Thermal Cycling Stability}

After the initial electrochemical performance investigation, we measured the thermal cycling performance of the tubular single cell between 800 and $25^{\circ} \mathrm{C}$. Figure 8 shows the performance stability of the single cell with the optimum cathode thickness of $15 \mu \mathrm{m}$ at the current density of $600 \mathrm{~mA} \mathrm{~cm}^{-2}$. The single cell could maintain $95 \%$ of its initial electrochemical performance within five thermal cycles, which is much improved compare with the conventional Ni-YSZ anode supported tubular cell (performance degradation is over $10 \%$ in two to three thermal cycles; Guan et al., 2011; Howe et al., 2013). The improved thermal cycling performance illustrates excellent mechanical compatibility between the different layers in the cell. The result suggests the advantage of the inert-substrate-supported tubular single cell for repeated startup and shut down power applications. 


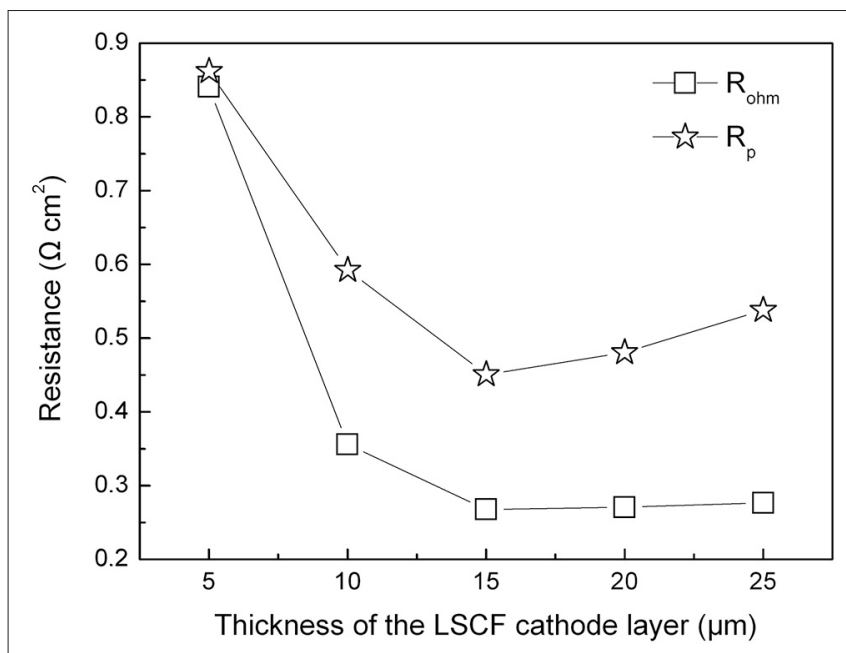

FIGURE 6 | Ohmic and polarization resistances of the tubular single cells with different cathode thicknesses at $800^{\circ} \mathrm{C}$.

\section{DISCUSSION}

\section{Microstructural Characterization}

To investigate the effects of cathode microstructures on the electrochemical performance of the tubular single cells, we analyzed SEM images of the cathode layer by the image-analysis method (Iwanschitz et al., 2012). Figure 9 shows the average grain size, pore diameter and porosity of the cathode layer estimated by the Image-pro plus software. By changing the cathode thickness through repetitive dip-coating processes, the layer presented similar average grain size $(0.9-1.0 \mu \mathrm{m})$, pore diameter $(550-750 \mathrm{~nm})$, and porosity $(30-40 \%)$, respectively.

The LSCF is widely recognized as an electronic-ionic mixed conducting cathode material. Hence, the electrochemical active region for oxygen reduction is extended out from the cathode/electrolyte interface (Adler et al., 1996; Lu et al., 2012). The range of the electrochemically active cathode region can be characterized by the length $\left(l_{\delta}\right)$ beyond the cathode/electrolyte interface, which can be estimated by the oxygen transport properties of the cathode materials and microstructural features of the layer as described by the following equation (EndlerSchuck et al., 2015):

$$
l_{\delta}=\left(((1-\varepsilon) / \tau) \cdot L_{c} / \alpha\right)^{1 / 2}
$$

where $\varepsilon$ is the porosity of the electrode, $\tau$ is the tortuosity of the electrode, $\alpha$ refers to the internal surface area per unit volume, and $L_{c}$ is the ratio between the oxygen diffusion coefficient and the surface oxygen exchange coefficient of the LSCF cathode material.

Based on the microstructural parameters determined from SEM image analysis, the three-dimensional porosity $\left(\varepsilon_{3 \mathrm{~d}}\right)$ of the cathode was calculated from the two-dimensional porosity $\left(\varepsilon_{2 \mathrm{~d}}\right)$ by the following equation (Hoomans et al., 1996):

$$
\varepsilon_{3 d}=1-2 / \sqrt{\Pi \cdot \sqrt{3}} \cdot\left(1-\varepsilon_{2 d}\right)^{3 / 2}
$$

The value of the tortuosity $\tau$ was calculated according to an empirical equation (Yang et al., 2013):

$$
\tau=\left(1-\varepsilon_{3 d}\right)^{-1 / 2}
$$

The internal surface area per unit volume was determined by the following equation:

$$
\alpha=6 / d_{a v}
$$

where the $d_{\mathrm{av}}$ refers to the average grain size of the LSCF cathode.

According to the reported oxygen diffusion coefficient (8.06 $\left.\times 10^{-6} \mathrm{~cm}^{2} \mathrm{~s}^{-1}\right)$ and surface oxygen exchange coefficient $(1.50 \times$ $10^{-4} \mathrm{~cm} \mathrm{~s}^{-1}$ ) for the LSCF material at $800^{\circ} \mathrm{C}$, the electrochemical active region $\left(l_{\delta}\right)$ for oxygen reduction reaction at the cathode was calculated (Lane and Kilner, 2000). The detailed microstructural parameters are listed in the Supplementary Material (Table S3). According to this investigation, the electrochemically active region was determined to be $\sim 8 \mu \mathrm{m}$ for the LSCF cathode with the thickness between 10 and $25 \mu \mathrm{m}$.

\section{Electrochemical Performance Investigation}

Electrochemical impedance spectra of the tubular single cells were fitted by the $L R_{\text {ohm }}\left(R_{\mathrm{H}} Q_{\mathrm{H}}\right)\left(R_{\mathrm{L}} Q_{\mathrm{L}}\right)$ equivalent circuit model. The fitting results are shown in Table S2 in the Supplementary Material. The equivalent capacitance and relaxation frequency for high frequency arcs are on the order of $10^{-1}-10^{-2} \mathrm{~F} \mathrm{~cm}^{-2}$ and $10^{0}-10^{1} \mathrm{~Hz}$, respectively. The electrochemical processes associated with these high frequency $\operatorname{arcs}\left(R_{\mathrm{H}} Q_{\mathrm{H}}\right)$ can be ascribed to the oxygen exchange process on the electrode surface (Escudero et al., 2007; Leonide et al., 2008). On the other hand, the equivalent capacitance and relaxation frequency for low frequency arcs are on the order of $10^{0} \mathrm{~F} \mathrm{~cm}^{-2}$ and $10^{-1} \mathrm{~Hz}$, respectively. The electrochemical process corresponding to these low frequency $\operatorname{arcs}\left(R_{\mathrm{L}} Q_{\mathrm{L}}\right)$ can be ascribed to the oxygen diffusion process (Escudero et al., 2007; Philippeau et al., 2013).

As the anode and electrolyte structures of the tubular single cells were kept constant in this research, the variations of high and low frequency arcs could be ascribed to the cathode layer. As indicated in Table S2, the area specific resistance from the high frequency arc $\left(R_{\mathrm{H}}\right)$ decreased by $50 \%$ (from 0.52 to $0.25 \Omega \mathrm{cm}^{2}$ ) when increasing the cathode thickness from 5 to $10 \mu \mathrm{m}$. This reduction of $R_{\mathrm{H}}$ could be due to the enlarged electrochemical active region of the cathode for the surface oxygen reduction reaction. Further increasing the thickness beyond $10 \mu \mathrm{m}$, the $R_{\mathrm{H}}$ showed a slightly increasing trend. The results illustrated that the surface oxygen reduction reaction was active within $10 \mu \mathrm{m}$ from the cathode/electrolyte interface, which is in good agreement with the electrochemical active region $\left(l_{\delta}: \sim 8 \mu \mathrm{m}\right)$ determined by the microstructural analysis.

On the other hand, the area specific resistance from the low frequency arc $\left(R_{\mathrm{L}}\right)$ decreased from 0.34 to $0.17 \Omega \mathrm{cm}^{2}$ by increasing the cathode thickness from 5 to $15 \mu \mathrm{m}$. The reduced $R_{\mathrm{L}}$ could be due to the increased total surface area of the cathode for the oxygen adsorption process. However, increasing the cathode thickness beyond $15 \mu \mathrm{m}$ tended to increase $R_{\mathrm{L}}$. 

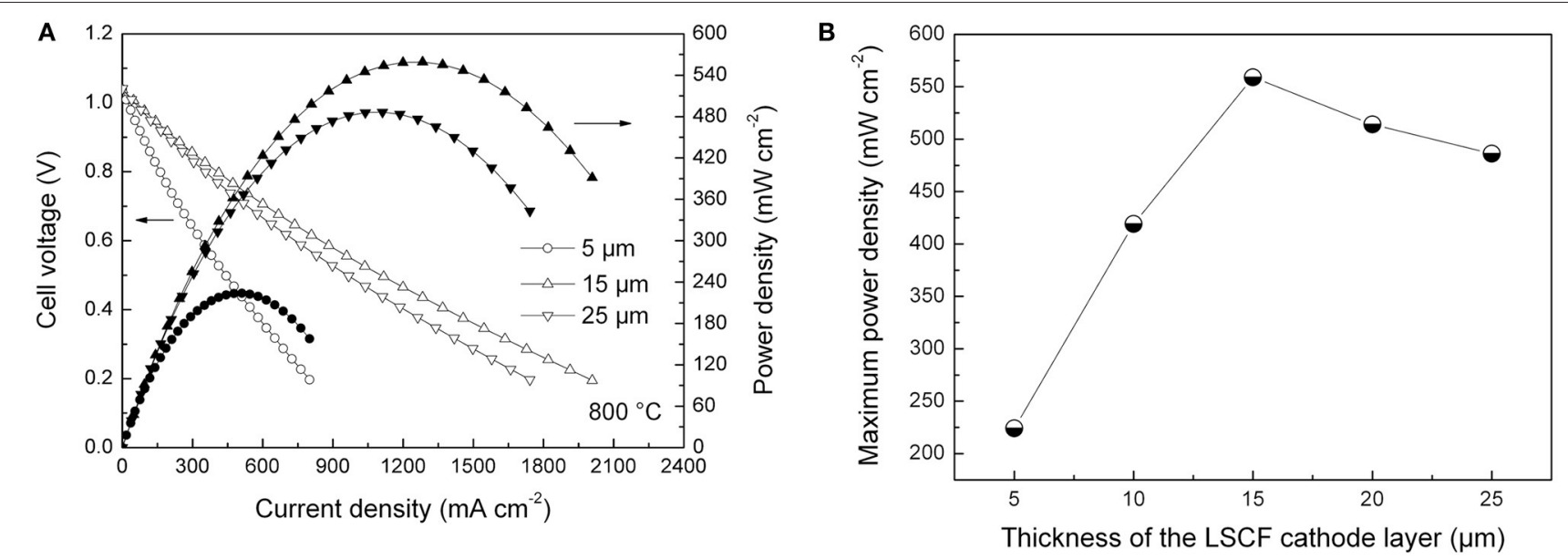

FIGURE 7 | (A) Current-voltage curves of the single cells with different cathode thicknesses, and (B) Maximum power density of the single cells as the function of cathode thickness.

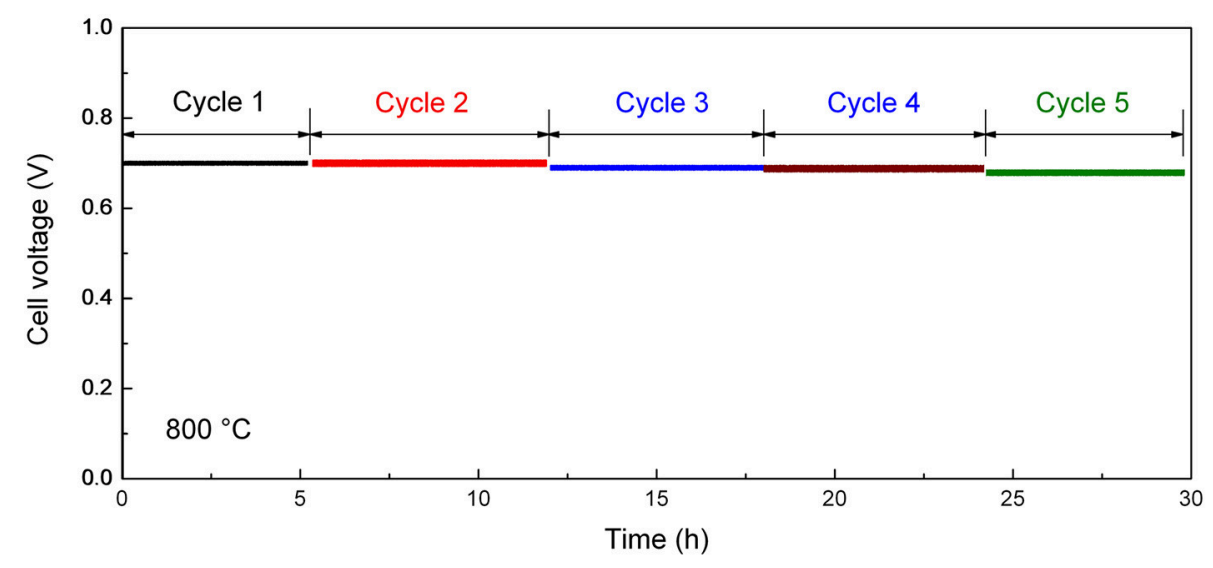

FIGURE 8 | Thermal cycling performance of the tubular single cell at $600 \mathrm{~mA} \mathrm{~cm}^{-2}$ at $800^{\circ} \mathrm{C}$.
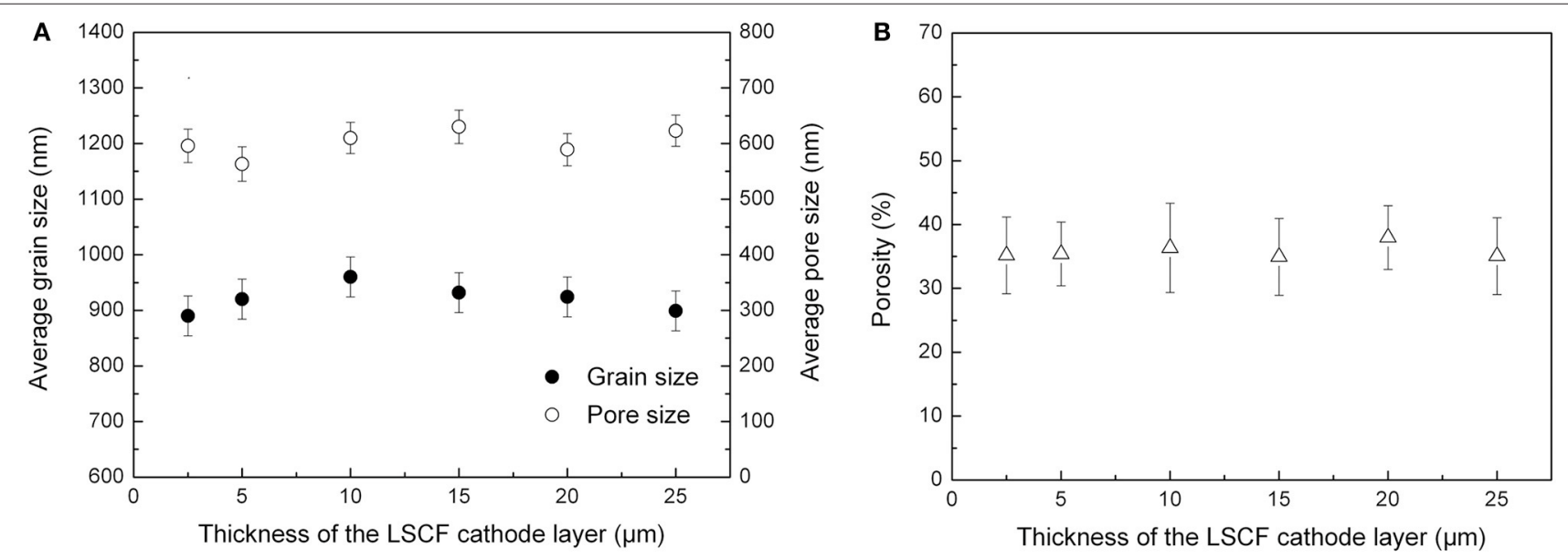

FIGURE 9 | (A) Average grain size and pore diameter in the cathode layer, and (B) Porosity of the cathode. 
For the single cells with the thicker cathode $(>15 \mu \mathrm{m})$, the adsorbed oxygen has to diffuse through a longer path to the electrochemically active region, which could increase the value of $R_{\mathrm{L}}$ (Hildenbrand et al., 2013). Additionally, thicker cathode layers would impede the diffusion of oxygen gas in the porous cathode, thus increasing the $R_{\mathrm{L}}$ of the single cells. Considering the variations of $R_{\mathrm{H}}$ and $R_{\mathrm{L}}$ values as the function of cathode thickness, the optimum thickness was determined to be $15 \mu \mathrm{m}$ for the LSCF layer. Thus, the single cell with this optimum thickness of the cathode layer showed the highest maximum power density of $559 \mathrm{~mW} \mathrm{~cm}^{-2}$ at $800^{\circ} \mathrm{C}$ in this work.

\section{CONCLUSION}

Inert-substrate-supported tubular single cells with multifunctional layers were fabricated by extrusion and slurry dip-coating processes. The microstructure of the LSCF cathode layer was modified by controlling the number of dip-coating steps in the cell fabrication procedure. The grain sizes (899$920 \mathrm{~nm})$, pore diameters (563-623 nm) and porosities (35-38\%) of the LSCF cathode were found to remain constant, while the thickness was increased from 2.5 to $25 \mu \mathrm{m}$. The electrochemical performance of the tubular single cells was examined with respect to the cathode thickness. Increasing the cathode thickness was found to lower the sheet resistance of the layer and ohmic resistance $\left(R_{\mathrm{ohm}}\right)$ of the single cell. Generally, increasing the cathode thickness from 2.5 to $15 \mu \mathrm{m}$ was beneficial for enhancing both the surface oxygen exchange process $\left(R_{\mathrm{H}} Q_{\mathrm{H}}\right)$ and oxygen diffusion and adsorption processes $\left(R_{\mathrm{L}} Q_{\mathrm{L}}\right)$. Further increasing the cathode thickness $(>15 \mu \mathrm{m})$ induced higher area specific resistance originating from the slow diffusion process

\section{REFERENCES}

Adler, S. B. (2004). Factors governing oxygen reduction in solid oxide fuel cell cathodes. Chem. Rev. 104, 4791-4844. doi: 10.1021/cr020724o

Adler, S. B., Lane, J. A., and Steele, B. C. H. (1996). Electrode kinetics of porous mixed-conducting oxygen electrodes. J. Electrochem. Soc. 143, 3554-3564. doi: $10.1149 / 1.1837252$

Aruna, S. T., Muthuraman, M., and Patil, K. C. (1998). Synthesis and properties of Ni-YSZ cermet: anode material for solid oxide fuel cells. Solid State Ionics 111, 45-51. doi: 10.1016/S0167-2738(98)00187-8

Chen, D., Ran, R., Zhang, K., Wang, J., and Shao, Z. (2009). Intermediatetemperature electrochemical performance of a polycrystalline $\mathrm{PrBaCo}_{2} \mathrm{O}_{5+\delta}$ cathode on samarium-doped ceria electrolyte. J. Power Sources 188, 96-105. doi: 10.1016/j.jpowsour.2008.11.045

Chen, M., Kim, B. H., Xu, Q., Ahn, B. K., Kang, W. J., and Huang, D. P. (2009). Synthesis and electrical properties of $\mathrm{Ce}_{0.8} \mathrm{Sm}_{0.2} \mathrm{O}_{1.9}$ ceramics for ITSOFC electrolytes by urea-combustion technique. Ceram. Int. 35, 1335-1343. doi: 10.1016/j.ceramint.2008.06.014

Chen, M., Kim, B. H., Xu, Q., Nam, O. J., and Ko, J. H. (2008). Synthesis and performances of N-SDC cermets for IT-SOFC anode. J. Eur. Ceram. Soc. 28, 2947-2953. doi: 10.1016/j.jeurceramsoc.2008.05.009.

Ciucci, F., and Chen, C. (2015). Analysis of electrochemical impedance spectroscopy data using the distribution of relaxation times: a bayesian and hierarchical bayesian approach. Electrochim. Acta 167, 439-454. doi: $10.1016 /$ j.electacta.2015.03.123

Eguchi, K. (1997). Ceramic materials containing rare earth oxides for solid oxide fuel cell. J. Alloys Compd. 250, 486-491. doi: 10.1016/S0925-8388(96)02629-1
$\left(R_{\mathrm{L}} Q_{\mathrm{L}}\right)$. Thus, the optimum thickness of the LSCF cathode layer was determined to be $15 \mu \mathrm{m}$ for the inert-substrate-supported tubular single cell. At $800^{\circ} \mathrm{C}$, the tubular single cell with the optimum cathode thickness showed a high maximum power density of $559 \mathrm{~mW} \mathrm{~cm}^{-2}$ under the hydrogen/air operation mode. Additionally, the tubular single cell exhibited a good thermal cycling stability during five cycles between 800 and $25^{\circ} \mathrm{C}$. The results illustrate advantages for future applications where the repeated startup and shut down condition mode is important.

\section{AUTHOR CONTRIBUTIONS}

$\mathrm{KZ}$ carried most of the experimental work on the tubular single cell, and drafted the manuscript. B-HK advised $\mathrm{KZ}$ in designing the tubular single cell configuration and helped him test the electrochemical performance. MN discussed the experimental results with $\mathrm{KZ}$ and offered comments to improve the research. $\mathrm{SH}$ discussed the experimental results with $\mathrm{KZ}$ and offered advice in organizing the research manuscript.

\section{FUNDING}

This work was supported financially by the Office of Naval Research (Grant No. N00014-15-1-2416).

\section{SUPPLEMENTARY MATERIAL}

The Supplementary Material for this article can be found online at: https://www.frontiersin.org/articles/10.3389/fenrg. 2018.00087/full\#supplementary-material

Endler-Schuck, C., Joos, J., Niedrig, C., Weber, A., and Ivers-Tiffée, E. (2015). The chemical oxygen surface exchange and bulk diffusion coefficient determined by impedance spectroscopy of porous $\mathrm{La}_{0.58} \mathrm{Sr}_{0.4} \mathrm{Co}_{0.2} \mathrm{Fe}_{0.8} \mathrm{O}_{3-\delta}$ (LSCF) cathodes. Solid State Ionics 269, 67-79. doi: 10.1016/j.ssi.2014.11.018

Escudero, M. J., Aguadero, A., Alonso, J. A., and Daza, L. (2007). A kinetic study of oxygen reduction reaction on $\mathrm{La}_{2} \mathrm{NiO}_{4}$ cathodes by means of impedance spectroscopy. J. Electroanal. Chem. 611, 107-116. doi: 10.1016/j.jelechem.2007.08.006

Fu, C., Chan, S. H., Liu, Q., Ge, X., and Pasciak, G. (2010). Fabrication and evaluation of Ni-GDC composite anode prepared by aqueous-based tape casting method for low-temperature solid oxide fuel cell. Int. J. Hydrogen Energy 35, 301-307. doi: 10.1016/j.ijhydene.2009.09.101

Gong, M., Gemmen, R. S., and Liu, X. (2012). Modeling of oxygen reduction mechanism for $3 \mathrm{~PB}$ and $2 \mathrm{~PB}$ pathways at solid oxide fuel cell cathode from multi-step charge transfer. J. Power Sources 201, 204-218. doi: 10.1016/j.jpowsour.2011.11.002

Gostovic, D., Smith, J., Kundinger, D., Jones, K., and Wachsman, E. (2007). Threedimensional reconstruction of porous LSCF cathodes. Electrochem. Solid-State Lett. 10, B214-B217. doi: 10.1149/1.2794672

Gourba, E., Briois, P., Ringuedé, A., Cassir, M., and Billard, A. (2004). Electrical properties of gadolinia-doped ceria thin films deposited by sputtering in view of SOFC application. J. Solid State Electrochem. 8, 633-637. doi: 10.1007/s10008-004-0503-3

Guan, Y., Gong, Y., Li, W., Gelb, J., Zhang, L., Liu, G., et al. (2011). Quantitative analysis of micro structural and conductivity evolution of Ni-YSZ anodes during thermal cycling based on nano-computed tomography. J. Power Sources 196, 10601-10605. doi: 10.1016/j.jpowsour.2011.08.083. 
Hayashi, H., Saitou, T., Maruyama, N., Inaba, H., Kawamura, K., and Mori, M. (2005). Thermal expansion coefficient of yttria stabilized zirconia for various yttria contents. Solid State Ionics 176, 613-619. doi: 10.1016/j.ssi.2004.08.021

Hildenbrand, N., Nammensma, P., Blank, D. H. A., Bouwmeester, H. J. M., and Boukamp, B. A. (2013). Influence of configuration and microstructure on performance of $\mathrm{La}_{2} \mathrm{NiO}_{4+\delta}$ intermediate-temperature solid oxide fuel cells cathodes. J. Power Sources 238, 442-453. doi: 10.1016/j.jpowsour.2013.03.192

Hoomans, B. P. B., Kuipers, J. A. M., Briels, W. J., and van Swaaij, W. P. M. (1996). Discrete particle simulation of bubble and slug formation in a twodimensional gas-fluidised bed: a hard-sphere approach. Chem. Eng. Sci. 51, 99-118. doi: 10.1016/0009-2509(95)00271-5

Howe, K. S., Hanifi, A. R., Kendall, K., Zazulak, M., Etsell, T. H., and Sarkar, P. (2013). Performance of microtubular SOFCs with infiltrated electrodes under thermal cycling. Int. J. Hydrogen Energy 38, 1058-1067. doi: 10.1016/j.ijhydene.2012.10.098.

Iwanschitz, B., Holzer, L., Mai, A., and Schütze, M. (2012). Nickel agglomeration in solid oxide fuel cells: the influence of temperature. Solid State Ionics 211, 69-73. doi: 10.1016/j.ssi.2012.01.015

Kirubakaran, A., Jain, S., and Nema, R. K. (2009). A review on fuel cell technologies and power electronic interface. Renew. Sust. Energ. Rev. 13, 2430-2440. doi: 10.1016/j.rser.2009.04.004

Küngas, R., Kivi, I., Lust, K., Nurk, G., and Lust, E. (2009). Statistical method to optimize the medium temperature solid oxide fuel cell electrode materials. $J$. Electroanal. Chem. 629, 94-101. doi: 10.1016/j.jelechem.2009.01.033

Lane, J. A., and Kilner, J. A. (2000). Measuring oxygen diffusion and oxygen surface exchange by conductivity relaxation. Solid State Ionics 136-137, 997-1001. doi: 10.1016/S0167-2738(00)00554-3

Leonide, A., Sonn, V., Weber, A., and Ivers-Tiffée, E. (2008). Evaluation and modeling of the cell resistance in anode-supported solid oxide fuel cells. J. Electrochem. Soc. 155, B36-B41. doi: 10.1149/1.2801372

Li, Y., Gemmen, R., and Liu, X. (2010). Oxygen reduction and transportation mechanisms in solid oxide fuel cell cathodes. J. Power Sources 195, 3345-3358. doi: 10.1016/j.jpowsour.2009.12.062

Lu, Z., Hardy, J., Templeton, J., and Stevenson, J. (2012). Extended reaction zone of $\mathrm{La}_{0.6} \mathrm{Sr}_{0.4} \mathrm{Co}_{0.2} \mathrm{Fe}_{0.8} \mathrm{O}_{3}$ cathode for solid oxide fuel cell. J. Power Sources 198, 90-94. doi: 10.1016/j.jpowsour.2011.09.020

Mineshige, A., Izutsu, J., Nakamura, M., Nigaki, K., Abe, J., Kobune, M., et al. (2005). Introduction of A-site deficiency into $\mathrm{La}_{0.6} \mathrm{Sr}_{0.4} \mathrm{Co}_{0.2} \mathrm{Fe}_{0.8} \mathrm{O}_{3-\delta}$ and its effect on structure and conductivity. Solid State Ionics 176, 1145-1149. doi: 10.1016/j.ssi.2004.11.021

Murata, K., Fukui, T., Abe, H., Naito, M., and Nogi, K. (2005). Morphology control of $\mathrm{La}(\mathrm{Sr}) \mathrm{Fe}(\mathrm{Co}) \mathrm{O}_{3-\mathrm{a}}$ cathodes for IT-SOFCs. J. Power Sources 145, 257-261. doi: 10.1016/j.jpowsour.2004.12.063

Orera, V. M., Laguna-Bercero, M. A., and Larrea, A. (2014). Fabrication methods and performance in fuel cell and steam electrolysis operation modes of small tubular solid oxide fuel cells: a review. Front. Energy Res. 2, 1-13. doi: 10.3389/fenrg.2014.00022

Perry Murray, E., Sever, M. J., and Barnett, S. A. (2002). Electrochemical performance of $(\mathrm{La}, \mathrm{Sr})(\mathrm{Co}, \mathrm{Fe}) \mathrm{O}_{3}-(\mathrm{Ce}, \mathrm{Gd}) \mathrm{O}_{3}$ composite cathodes. Solid State Ionics 148, 27-34. doi: 10.1016/S0167-2738(02)00102-9

Philippeau, B., Mauvy, F., Mazataud, C., Fourcade, S., and Grenier, J. C. (2013). Comparative study of electrochemical properties of mixed conducting $\mathrm{Ln}_{2} \mathrm{NiO}_{4+\delta} \quad(\mathrm{Ln}=\mathrm{La}, \quad \mathrm{Pr}$ and $\mathrm{Nd})$ and $\mathrm{La}_{0.6} \mathrm{Sr}_{0.4} \mathrm{Fe}_{0.8} \mathrm{Co}_{0.2} \mathrm{O}_{3-\delta}$ as SOFC cathodes associated to $\mathrm{Ce}_{0.9} \mathrm{Gd}_{0.1} \mathrm{O}_{2-\delta}, \mathrm{La}_{0.8} \mathrm{Sr}_{0.2} \mathrm{Ga}_{0.8} \mathrm{Mg}_{0.2} \mathrm{O}_{3-\delta}$ and $\mathrm{La}_{9} \mathrm{Sr}_{1} \mathrm{Si}_{6} \mathrm{O}_{26.5}$ electrolytes. Solid State Ionics 249-250, 17-25. doi: 10.1016/j.ssi.2013.06.009

Sameshima, S., Ichikawa, T., Kawaminami, M., and Hirata, Y. (1999). Thermal and mechanical properties of rare earth-doped ceria ceramics. Mater. Chem. Phys. 61, 31-35. doi: 10.1016/S0254-0584(99)00109-1
Sarantaridis, D., and Atkinson, A. (2007). Redox cycling of Ni-based solid oxide fuel cell anodes: a review. Fuel Cells 7, 246-258. doi: 10.1002/fuce.200600028

Shri Prakash, B., Senthil Kumar, S., and Aruna, S. T. (2014). Properties and development of Ni/YSZ as an anode material in solid oxide fuel cell: a review. Renew. Sust. Energ. Rev. 36, 149-179. doi: 10.1016/j.rser.2014.04.043

Singhal, S. C. (2012). "Solid oxide fuel cells: past, present and future," in Solid Oxide Fuels Cells: Facts and Figures: Past Present and Future Perspectives for SOFC Technologies. London: Springer London, 1-23.

Stambouli, A. B., and Traversa, E. (2002). Solid oxide fuel cells (SOFCs): a review of an environmentally clean and efficient source of energy. Renew. Sust. Energ. Rev. 6, 433-455. doi: 10.1016/S1364-0321(02)00014-X

Su, C., Wang, W., Ran, R., Shao, Z., Tade, M. O., and Liu, S. (2013). Renewable acetic acid in combination with solid oxide fuel cells for sustainable clean electric power generation. J. Mater. Chem. A 1, 5620-5627. doi: $10.1039 / \mathrm{c} 3$ ta10538e

Tikkanen, H., Suciu, C., Wærnhus, I., and Hoffmann, A. C. (2011). Dip-coating of 8YSZ nanopowder for SOFC applications. Ceram. Int. 37, 2869-2877. doi: 10.1016/j.ceramint.2011.05.006

Wan, T. H., Saccoccio, M., Chen, C., and Ciucci, F. (2015). Influence of the discretization methods on the distribution of relaxation times deconvolution: implementing radial basis functions with DRTtools. Electrochim. Acta 184, 483-499. doi: 10.1016/j.electacta.2015.09.097

Yakabe, H., Baba, Y., Sakurai, T., and Yoshitaka, Y. (2004). Evaluation of the residual stress for anode-supported SOFCs. J. Power Sources 135, 9-16. doi: 10.1016/j.jpowsour.2003.11.049

Yamaguchi, T., Suzuki, T., Shimizu, S., Fujishiro, Y., and Awano, M. (2007). Examination of wet coating and co-sintering technologies for micro-SOFCs fabrication. J. Memb. Sci. 300, 45-50. doi: 10.1016/j.memsci.2007.05.002

Yang, X. H., Lu, T. J., and Kim, T. (2013). A simplistic model for the tortuosity in two-phase close-celled porous media. J. Phys. D Appl. Phys. 46, 125305-125308. doi: $10.1088 / 0022-3727 / 46 / 12 / 125305$

Zha, S. W., Xia, C. R., and Meng, G. Y. (2001). Calculation of the e.m.f. of solid oxide fuel cells. J. Appl. Electrochem. 31, 93-98. doi: 10.1023/a:1004138703860

Zhao, K., Kim, B. H., Du, Y., Xu, Q., and Ahn, B. G. (2016). Ceria catalyst for inertsubstrate-supported tubular solid oxide fuel cells running on methane fuel. $J$. Power Sources 314, 10-17. doi: 10.1016/j.jpowsour.2016.02.079

Zhao, K., Kim, B. H., Xu, Q., and Ahn, B. G. (2014). Fabrication and characterization of inert-substrate-supported tubular single cells by dip-coating process. J. Power Sources 245, 671-677. doi: 10.1016/j.jpowsour.2013.07.022

Zhao, K., Lee, K. S., Chen, M., Kim, B. H., Xu, Q., and Ahn, B. G. (2013). Electrochemical performance of a copper-impregnated $\mathrm{Ni}-\mathrm{Ce}_{0.8} \mathrm{Sm}_{0.2} \mathrm{O}_{1.9}$ anode running on methane. Int. J. Hydrogen Energy 38, 3750-3756. doi: 10.1016/j.ijhydene.2013.01.036

Zhao, K., Xu, Q., Huang, D.-P., Chen, M., and Kim, B. H. (2011). Microstructure and electrode properties of $\mathrm{La}_{0.6} \mathrm{Sr}_{0.4} \mathrm{Co}_{0.2} \mathrm{Fe}_{0.8} \mathrm{O}_{3-\delta}$ spin-coated on $\mathrm{Ce}_{0.8} \mathrm{Sm}_{0.2} \mathrm{O}_{2-\delta}$ electrolyte. Ionics 17, 247-254. doi: $10.1007 /$ s11581-010-0507-1

Conflict of Interest Statement: The authors declare that the research was conducted in the absence of any commercial or financial relationships that could be construed as a potential conflict of interest.

Copyright (c) 2018 Zhao, Kim, Norton and Ha. This is an open-access article distributed under the terms of the Creative Commons Attribution License (CC BY). The use, distribution or reproduction in other forums is permitted, provided the original author(s) and the copyright owner(s) are credited and that the original publication in this journal is cited, in accordance with accepted academic practice. No use, distribution or reproduction is permitted which does not comply with these terms. 